\title{
Faktor - faktor riwayat ibu yang menyebabkan terjadinya stunting pada balita usia 6-59 bulan di Lampung Tengah
}

\author{
Yesi Nurmalasari ${ }^{*}$, Festy Ladyani Mustofa², Wulandari ${ }^{3}$ \\ 1,2,3 Fakultas Kedokteran Universitas Malahayati Bandar Lampung, Indonesia. \\ *Email: yesinurmalasari.dr@gmail.com
}

\begin{abstract}
Factors associated with stunting among children of age 6 to 59 months in Central Lampung, Indonesia

Background: Stunting is a chronic condition that describes the inhibition of growth for the long-term malnutrition, causing stunting is two directly and indirectly. Indirect causes are factors of education, history of the antenatal care (ANC), granting exclusive breastfeeding, maternal nutritional status, consumption of iron ( $\mathrm{Fe})$, occupational factors, and economic status.

Purpose: To determine the Factors associated with stunting among children of age 6 to 59 months in Central Lampung, Indonesia

Methods: Its quantitative descriptive cross-sectional design with total sampling. The sample is toddlers aged 5-59 months of 106 toddlers. The location was conducted in the village of Mataram llir, Seputih District, Surabaya,

Central Lampung in 2019. Research instruments in the form of questionnaires, scales, Microtois/Staturmeter and midline. This research has passed research ethics with ethics number no. 62 / EC / KEP-UNMAL / 2019.

Results: There are of $54,2 \%$ of women not breastfeeding, $74.0 \%$ never pay attention for antenatal care during pregnancy, $71,9 \%$ of mothers suffer from chronic energy deficiency (CED), 52,1\% of mothers never consume iron (Fe) during pregnant, and there were of $50.0 \%$ has a poor knowledge due to less education.

Conclusion: Factors of maternal of an indirect cause stunting is exclusive breastfeeding, consumption of iron $(\mathrm{Fe})$, maternal nutritional status, history of the antenatal care and maternal education level can cause stunting to the children of age 6 to 59 Months.
\end{abstract}

\section{Keywords: Socio-Economic; Maternal Nutritional Status; Stunting; Children of age 6 to 59 Months}

Pendahuluan: Stunting merupakan kondisi kronis yang menggambarkan terhambatnya pertumbuhan karena malnutrisi jangka panjang, penyebab stunting terbagi dua yaitu secara langsung dan tidak langsung. penyebab tidak langsungnya adalah faktor pendidikan,riwayat ANC,Pemberian asi eksklusif , status gizi ibu,konsumsi zat besi (fe), faktor pekerjaan, dan status ekonomi keluarga

Tujuan: Untuk mengetahui faktor-faktor riwayat ibu yang menyebabkan terjadinya stunting pada balita $6-59$ bulan di desa mataram ilir kecamatan seputih surabaya lampung tengah tahun 2019.

Metode: Penelitian deskriptif kuantitatif dengan rancangan cross sectional dengan menggunakan total sampling. Sampel penelitian adalah balita usia 5-59 bulan berjumlah 106 balita. Tempat penelitian dilakukan di desa Mataram Ilir , Kecamatan Seputih Surabaya, Lampung Tengah tahun 2019. Instrumen penelitian berupa kuesioner, timbangan, mikrotois dan midline. Penelitian ini sudah lulus etik penelitian dengan nomor etik no.62/EC/KEP-UNMAL/2019.

Hasil: Didapatkan $54,2 \%$ ibu yang tidak memberikan ASI Eksklusif, $74,0 \%$ ibu tidak melakukan perawatan ANC Saat hamil, $71,9 \%$ ibu menderita KEK, 52,1\% ibu tidak mengkonsumsi zat besi (Fe) saat hamil, dan terdapat $50,0 \%$ ibu berpendidikan rendah.

Simpulan: Faktor-faktor riwayat ibu secara tidak langsung yang menyebabkan stunting yaitu pemberian ASI Eksklusif, riwayat konsumsi zat besi (Fe), status gizi ibu ,riwayat ANC dan tingkat pendidikan ibu dapat menyebabkan terjadinya stunting pada balita usia 6-59.

Kata Kunci: Riwayat Ibu; Stunting; Balita Usia 6 - 59 Bulan 
Faktor - faktor riwayat ibu yang menyebabkan terjadinya stunting pada balita usia 6-59 bulan di Lampung Tengah

\section{PENDAHULUAN}

Stunting merupakan kondisi kronis yang menggambarkan terhambatnya pertumbuhan karena malnutrisi jangka panjang. Stunting menurut WHO Child Growth Standart didasarkan pada indeks panjang badan dibanding umur (PB/U) atau tinggi badan dibanding umur (TB/U) dengan batas (z-score) kurang Dari -2 SD. (World Health Organization (WHO). Proses menjadi pendek atau stunting pada anak di suatu wilayah atau daerah miskin dimulai sejak usia sekitar 6 bulan dan muncul utamanya pada dua sampai tiga tahun awal kehidupan serta berlangsung terus sampai usia 18 tahun (Wahdah, 2012). Stunting pada balita perlu menjadi perhatian khusus karena dapat menghambat perkembangan fisik dan mental anak. Faktor penyebab stunting menurut UNICEF secara komprehensif diuraikan menjadi faktor langsung dan tidak langsung. Banyak faktor yang dapat menyebabkan kejadian stunting pada balita.Faktorfaktor tersebut dapat berasal bersifat langsung dan tidak langsung. Penyebab langsung dari kejadian stunting adalah asupan makanan, tinggi badan orang tua, berat bayi lahir rendah (BBLR), dan riwayat penyakit infeksi sedangkan penyebab tidak langsungnya adalah faktor pendidikan,riwayat ANC,Pemberian asi eksklusif , status gizi ibu,konsumsi zat besi (fe) faktor pekerjaan, dan status ekonomi keluarga (Wellina, Kartasurya, \& Rahfiludin, 2016).

\section{METODE PENELITIAN}

Penelitian deskriptif dengan sampel balita usia 5-59 bulan berjumlah 106 balita. Tempat penelitian dilakukan di desa Mataram llir , Kecamatan Seputih Surabaya, Lampung Tengah tahun 2019. Waktu pelaksanaan dilakukan selama bulan Febuari 2019. Tehnik penelitian menggunakan total sampling yang telah memenuhi kriteria inklusi dan eklusi. Instrumen penelitian berupa kuesioner, timbangan, mikrotois dan midline. Kuesioner pemberian Asi-Eksklusif berjumlah 5 pertanyaan, sedangkan kuesioner pemberian tablet $\mathrm{Fe}$ dan ANC masing-masing berjumlah 2 pertanyaan, dengan nilai uji relliabilitas 0.769 dan uji validitas 0.306 . Sedangkan pengukuran status gizi ibu dan balita menggunakan timbangan, mikrotois dan midline. Penelitian ini sudah lulus etik penelitian dengan nomor etik no.62/EC/KEP-UNMAL/2019.

\section{HASIL}

Tabel 1. Distribusi Frekuensi Balita Stunting N=96

\begin{tabular}{lcc}
\hline Variabel & Frekuensi (f) & Persentase (\%) \\
\hline Stunting & & \\
Pendek & 68 & 70,8 \\
Sangat Pendek & 28 & 29,2 \\
Pemberian ASI & & \\
Dengan ASI Eksklusif & 44 & 45,8 \\
Tanpa ASI Eksklusif & 52 & 54,2 \\
\hline
\end{tabular}

Tabel 1. Menunjukkan bahwa frekuensi balita stunting berdasarkan tinggi badan atau panjang badan terhadap umur (TB/U), paling banyak ada pada balita stunting yang pendek yaitu sebanyak 68 orang dengan presentase $70,8 \%$ kemudian pada balita stunting yang sangat pendek yaitu sebanyak 28 orang dengan presentase $49,2 \%$. Distribusi frekuensi riwayat ibu berdasarkan pemberian ASI-Eksklusif sebanyak 44 dengan presentase $45,8 \%$ yang memberikan ASI-Eksklusif dan ada sebanyak 52 dengan presentase $54,2 \%$ ibu yang tidak memberikan ASI-Eksklusif. 
Faktor - faktor riwayat ibu yang menyebabkan terjadinya stunting pada balita usia 6-59 bulan di Lampung Tengah

Tabel 2. Distribusi Frekuensi Riwayat lbu N=96

\begin{tabular}{lcc}
\hline Variabel & Frekuensi (f) & Persentase (\%) \\
\hline Riwayat ANC & & \\
Teratur & 25 & 26,0 \\
Tidak Teratur & 71 & 74,0 \\
Status Gizi lbu & & \\
Normal & 27 & 28,1 \\
KEK & 69 & 71,9 \\
Riwayat Konsumsi Zat & & \\
Besi (Fe) & & \\
Konsumsi & 46 & 47,9 \\
Tidak konsumsi & 50 & 52,1 \\
Tingkat Pendidikan Ibu & & \\
Pendidikan Rendah & 48 & $50,0 \%$ \\
Penddikan Tinggi & 48 & $50,0 \%$ \\
\hline
\end{tabular}

Tabel 2. menunjukkan bahwa distribusi frekuensi riwayat ibu berdasarkan riwayat ANC sebanyak 25 orang dengan persentase $26,0 \%$ yang melakukan ANC secara teratur dan sebanyak 71 orang dengan persentase $74,0 \%$ yang tidak melakukan ANC secara tidak teratur. Distribusi frekuensi riwayat ibu berdasarkan status gizi ibu sebanyak 27 orang dengan persentase $28,1 \%$ yang normal atau tidak KEK dan sebanyak 69 orang dengan persentase $71,9 \%$ yang menderita KEK( kekurangan energi kronis ). Distribusi frekuensi riwayat ibu berdasarkan riwayat konsumsi zat besi $(\mathrm{Fe})$ pada saat kehamilan ada sebanyak 46 orang dengan persentase $47,9 \%$ yang mengkonsumsi tablet $\mathrm{Fe}$ dan ada sebanyak 50 orang $52,1 \%$ yang tidak mengkonsumsi tablet Fe. Distribusi frekuensi riwayat ibu berdasarkan tingkat pendidikan ibu sebanyak 48 orang dengan presentasi $50,0 \%$ berpendidikan rendah dan sebanyak 48 orang dengan presentasi $50,0 \%$ berpendidikan tinggi.

\section{PEMBAHASAN}

Distribusi frekuensi riwayat ibu berdasarkan pemberian ASI-Eksklusif sebanyak 44 orang dengan presentase $45,8 \%$ yang memberikan ASIEksklusif Pemberian ASI yang kurang sesuai di Indonesia menyebabkan bayi menderita gizi kurang dan gizi buruk. Padahal kekurangan gizi pada bayi akan berdampak pada gangguan psikomotor, kognitif dan sosial serta secara klinis terjadi gangguan pertumbuhan. Dampak lainnya adalah derajat kesehatan dan gizi anak Indonesia masih memprihatinkan (Haryono \& Setianingsih, 2014; Amaliah, Sari, \& Suryaputri, 2016; Di Benedetto, Bottanelli, Cattaneo, Pariante, \& Borsini, 2019; Walker, Wachs, GranthamMcGregor, Black, Nelson, \& Huffman, 2011; Pivina, Semenova, Doşa, Dauletyarova, \& Bjørklund, 2019).

Pertumbuhan dan perkembangan pada masa bayi memerlukan masukan zat-zat gizi yang seimbang dan relatif besar. Namun, kemampuan bayi untuk makan dibatasi oleh keadaan saluran pencernaannya yang masih dalam tahap pendewasaan. Satu-satunya makanan yang sesuai dengan keadaan saluran pencernaaan bayi dan memenuhi kebutuhan selama berbulan-bulan pertama adalah ASI (Maryunani, 2010). 
Faktor - faktor riwayat ibu yang menyebabkan terjadinya stunting pada balita usia 6-59 bulan di Lampung Tengah

Distribusi frekuensi riwayat ibu berdasarkan riwayat ANC sebanyak 25 orang dengan persentase $26,0 \%$ yang melakukan ANC secara teratur Kunjungan ANC yang dilakukan secara teratur dapat mendeteksi dini risiko kehamilan yang ada pada seorang ibu dan janinnya,terutama yang berkaitan dengan masalah gizi (Aguayo, Badgaiyan, \& Paintal, 2015). Berdasarkan status gizi ibu sebanyak 27 orang dengan persentase $28,1 \%$ yang normal atau tidak KEK dan sebanyak 69 orang dengan persentase $71,9 \%$ yang menderita KEK ( kekurangan energi kronis ). Keadaan kesehatan ibu sebelum dan selama kehamilan akan mempengaruhi status gizi ibu dan bayi. Asupan gizi ibu sangat mempengaruhi pertumbuhan dan perkembangan janin. Perempuan yang mengalami kekurangan gizi sebelum kehamilan atau selama minggu pertama kehamilan memiliki resiko lebih tinggi melahirkan bayi yang mengalami kerusakan otak dan sumsum tulang karena pembentukan sistem syaraf dimulai pada minggu ke dua sampai lima pertama kehamilan. Kekurangan gizi pada trimester akhir memiliki kecenderungan akan melahirkan bayi dengan berat badan lahir rendah $(<2.500$ gram) (Arisman, 2004; Elsandra, Made, Gunawan, \& Joko 2019; Arini, \& Firdaus, 2019; Ophie, Made, Gunawan, \& Tjarono, 2019; Rainforth, 2019).

Berdasarkan riwayat konsumsi zat besi $(\mathrm{Fe})$ pada saat kehamilan ada sebanyak 46 orang dengan persentase $47,9 \%$ yang mengkonsumsi tablet $\mathrm{Fe}$ dan ada sebanyak 50 orang $52,1 \%$ yang tidak mengkonsumsi tablet Fe. Zat besi berperan penting salah satu unsur yang diperlukan dalam proses pembentukan sel darah merah. Sel darah merah ini mengandung senyawa kimia bernama hemoglobin, yang berfungsi membawa oksigen dari paru dan mengantarkannya ke seluruh bagian tubuh. Kekurangan zat besi selama masa kehamilan bisa menyebabkan gangguan pertumbuhan pada janin. (World Health Organisatiton, 2014; Oktadianingsih, Irianto, Chandradewi, \& Jaya 2019; Mesdaghinia, Naderi, Bahmani, Chamani, Ghader, \& Asemi, 2019).

Berdasarkan tingkat pendidikan ibu sebanyak 48 orang dengan presentasi $50,0 \%$ berpendidikan rendah dan sebanyak 48 orang dengan presentasi $50,0 \%$ berpendidikan tinggi Tingkat pendidikan, khususnya tingkat pendidikan ibu mempengaruhi derajat kesehatan. Hal ini terkait peranannya yang paling banyak pada pembentukan kebiasaan makan anak, karena ibulah yang mempersiapkan makanan mulai mengatur menu, berbelanja, memasak, menyiapkan makanan, dan mendistribusikan makanan (Mita, \& Rina, 2019; Ye, Yan, Huang, Mao, Ge, Weng, \& Tao, 2019)

\section{SIMPULAN}

Distribusi frekuensi riwayat ibu berdasarkan pemberian ASI-Eksklusif sebanyak 44 orang dengan presentase $45,8 \%$ yang memberikan ASIEksklusif dan ada sebanyak 52 orang dengan presentase $54,2 \%$ ibu yang tidak memberikan ASI-Eksklusif, berdasarkan riwayat ANC sebanyak 25 orang dengan persentase $26,0 \%$ yang melakukan ANC secara teratur dan sebanyak 71 orang dengan persentase $74,0 \%$ yang tidak melakukan ANC secara tidak teratur, berdasarkan status gizi ibu sebanyak 27 orang dengan persentase $28,1 \%$ yang normal atau tidak KEK dan sebanyak 69 orang dengan persentase $71,9 \%$ yang menderita KEK ( kekurangan energi kronis ). Dari hasil tabel di atas menunjukan bahwa kurang nya kepedulian ibu terhadap status gizinya pada saat hamil. Berdasarkan riwayat konsumsi zat besi (Fe) pada saat kehamilan ada sebanyak 46 orang dengan persentase $47,9 \%$ yang mengkonsumsi tablet $\mathrm{Fe}$ dan ada sebanyak 50 orang $52,1 \%$ yang tidak mengkonsumsi tablet $\mathrm{Fe}$, berdasarkan tingkat pendidikan ibu sebanyak 48 orang dengan presentasi $50,0 \%$ berpendidikan rendah dan sebanyak 48 orang dengan presentasi $50,0 \%$ berpendidikan tinggi.

\section{DAFTAR PUSTAKA}

Aguayo, V. M., Badgaiyan, N., \& Paintal, K. (2015). Determinants of child stunting in the $R$ oyal $K$ ingdom of $B$ hutan: an in-depth analysis of nationally representative data. Maternal \& child nutrition, 11(3), 333-345.

Amaliah, N., Sari, K., \& Suryaputri, I. Y. (2016). Panjang Badan Lahir Pendek Sebagai Salah Satu Faktor Determinan Keterlambatan Tumbuh Kembang Anak Usia 6-23 Bulan Di Kelurahan Jaticempaka, Kecamatan Pondok Gede, Kota Bekasi. Jurnal ekologi kesehatan, 15(1), 43-55.

Arini, L. D. D., \& Firdaus, E. N. (2019). Pengaruh asupan dha dan protein pada ibu hamil terhadap berat badan dan panjang janin di rumah bersalin nissa tegalgede, karanganyar. Smiknas, 70-77. 
Faktor - faktor riwayat ibu yang menyebabkan terjadinya stunting pada balita usia 6-59 bulan di Lampung Tengah

Arisman, M. B. (2004). Gizi dalam daur kehidupan. Jakarta: EGC, 76-87.

Di Benedetto, M. G., Bottanelli, C., Cattaneo, A., Pariante, C. M., \& Borsini, A. (2019). Nutritional and immunological factors in breast milk: a role in the intergenerational transmission from maternal psychopathology to child development. Brain, behavior, and immunity.

Elsandra, D. M., Made, I., Gunawan, A., \& Joko, S. (2019). Kajian asupan kalsium dan sumber tanin pada kejadian anemia ibu hamil di kabupaten kulon progo tahun 2018 (Doctoral dissertation, Poltekkes Kemenkes Yogyakarta).

Haryono, R., \& Setianingsih, S. (2014). Manfaat ASI eksklusif untuk buah hati anda. Yogyakarta: Gosyen Publishing, 1-30.

Maryunani, A. (2010). IImu kesehatan anak dalam kebidanan. Jakarta: Trans Info Media

Mesdaghinia, E., Naderi, F., Bahmani, F., Chamani, M., Ghaderi, A., \& Asemi, Z. (2019). The effects of zinc supplementation on clinical response and metabolic profiles in pregnant women at risk for intrauterine growth restriction: a randomized, double-blind, placebo-controlled trial. The Journal of Maternal-Fetal \& Neonatal Medicine, 1-7.

Mita, A. A., \& Rina, O. (2019). Pendidikan orang tua, pengetahuan gizi ibu mengenai tumbuh kembang anak dan status gakin dengan kejadian stunting pada balita usia 24-59 bulan di wilayah kerja puskesmas karangmojo ii gunungkidul (Doctoral dissertation, Poltekkes Kemenkes Yogyakarta).

Oktadianingsih, D., Irianto, I., Chandradewi, A. A. S. P., \& Jaya, I. S. (2019). Penambahan berat badan ibu hamil terhadap berat bayi lahir di kota mataram. Jurnal Gizi Prima, 2(2), 76-85.

Ophie, H. I. M. T., Made, I., Gunawan, A., \& Tjarono, S. (2019). Kajian Asupan Protein dan Asam Folat Pada Ibu Hamil Anemia Di Wilayah Lokus Stunting Di Kabupaten Kulon Progo (Doctoral dissertation, Poltekkes Kemenkes Yogyakarta).
Pivina, L., Semenova, Y., Doşa, M. D., Dauletyarova, M., \& Bjørklund, G. (2019). Iron Deficiency, Cognitive Functions, and Neurobehavioral Disorders in Children. Journal of Molecular Neuroscience, 68(1), 1-10.

Rainforth, M. (2019). The effect of maternal nutritional restriction on fetal development and performance of offspring in beef cattle. Alberta Academic Review, 1(2), 1-11.

Wahdah, S. (2012). Faktor Risiko Kejadian Stunting pada Anak Umur 6-36 Bulan di Wilayah Pedalaman Kecamatan Silat Hulu Kabupaten Kapuas Hulu Provinsi Kalimantan Barat (Doctoral dissertation, Universitas Gadjah Mada).

Walker, S. P., Wachs, T. D., Grantham-McGregor, S., Black, M. M., Nelson, C. A., Huffman, S. L., \& Gardner, J. M. M. (2011). Inequality in early childhood: risk and protective factors for early child development. The lancet, 378(9799), 1325-1338.

Wellina, W. F., Kartasurya, M. I., \& Rahfiludin, M. Z. (2016). Faktor risiko stunting pada anak umur 12-24 bulan. Jurnal Gizi Indonesia (The Indonesian Journal of Nutrition), 5(1), 55-61.

Word Health Organization. (2014). Sasaran Gizi Global Ringkasan Kebijakan Pendek. Jenewa: Kesehatan Dunia Organisasi. Universitas Airlangga. Surabaya.

Ye, A., Yan, S., Huang, K., Mao, L., Ge, X., Weng, T., \& Tao, F. (2019). Maternal intelligence quotient and motor development in early childhood: The mediating role of mother's education. Journal of paediatrics and child health, 55(1), 87-94. 